\title{
Bjørnstjerne Bjørnson og Sønderjylland
}

En episode med eftervirkninger

Af Hans Lund.

Under et ophold på Askov Højskole d. 12.-14. nov. 1887 holdt Bjørnstjerne Bjørnson første gang det berømte foredrag Engifte og Mangegifte«, der var et indlæg i den sædelighedsdebat, der havde været ført i Danmark et par år, og som nåede sin kulmination i sidste halvdel af året 1887. I den følgende måned holdt han foredraget rundt omkring i Danmark, og gårdejer Skrumsager i Københoved fik da den tanke, at foredraget også burde holdes i Nordslesvig. Han skrev til slagtermester Reimers i Sønderborg og til redaktør. M. C. Mathiesen i Haderslev om sagen - måske har han skrevet til flere, men der findes $i$ hans arkiv ${ }^{1}$ kun svar fra disse to.

Reimers svarer d. 4. 12.: "Vel tror jeg, at der findes stemning for at høre hr. Bjørnstjerne Bjørnsons foredrag, men tilladelsen vil ikke gives under forudsætning af, at der tages indgangspenge. Tror du ikke, at tilladelsen kunne gives, når foredragsholderen som udlænding selv ansøger derom? Enhver kunstner e. 1. må være $\mathrm{i}$ besiddelse af concention (concession); jeg synes, du burde gøre forsøget for eder selv. Tillades det der, kan det jo fortsættes. - - "

Et par dage efter skriver M. C. Mathiesen til Skrumsager: "Jeg har efter modtagelsen af Deres brev tilladt mig ved en notits $i$ bladet at underrette publikum om, at Bjørnstjerne Bjørnson kan ventes her. Også for lokale skal jeg nok sørge; det bliver vel det rigtigste at leje theatret, forudsat at det ikke kan fås gratis. Derom kan der dog selvfølgelig kun være tale, når jeg har fået underretning om, hvornår foredraget skal afholdes.

Mussmann² vil være en meget passende vært for Bjørnson. Jeg skal ikke undlade at støtte en opfordring til ham $i$ den henseende, så meget mere som han er den eneste, hvorom der kan 


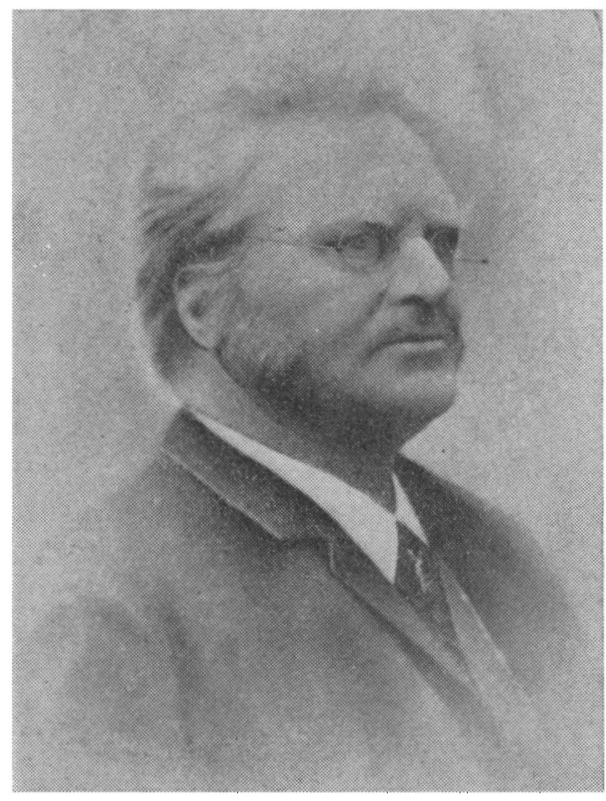

Bjørnstjerne Bjornson

være tale. Doktoren ${ }^{3}$ ynder nemlig ikke Bjørnson, og en anmodning til hr. Bjørnshauge ville sikkert kun blive besvaret med et afslag, navnlig under de forhåndenværende forhold.“ Skulle Mussmann ikke være tilbøjelig til at være vært, bliver der sandsynligvis næppe andet for, end at Bjørnson må bo på »Harmonien ", skjønt jeg just ikke vil anse et sådant arrangement for heldigt.

Forøvrigt synes der fra anden side at blive drevet en stærk agitation mod at få Bjørnson hertil. Man henviser til, at han $\mathbf{i}$ sit foredrag behandler spørgsmål, der ligger os fjernt, og som vi ikke trænger til at høre noget om, "fordi vi Gud ske Lov ikke er så forfaldne", hvad der vel vil sige så meget som: "Jeg takker dig Gud osv.«. Dernæst erklæres Bjørnson for at være en fusentast, der har "forandret signaler", og endelig gjøres opmærksom pâ, at tilhørerkredsen vil blive fuldstændig blandet, siden det ikke kan undgås at holde tyskerne uden for.

(Må være: gennemfores at holde tyskerne udenfor.)

At der imidlertid trods dette nok skal komme tilhørere i be- 
tydeligt antal, anser jeg for givet, men jeg har dog ikke villet undlade at gjøre Dem opmærksom på, hvad man har for."

Haderslev kunne imidlertid have sparet sig sine bekymringer, idet Bjørnson blev forhindret $i$ at tage dertil, og idet mødet blev forbudt. Den 10. dec. skriver Mathiesen igen til Skrumsager:

"Det vil sikkert være mange en skuffelse, at Bjørnstjerne Bjørnson ikke kommer hertil. Flere her i byen, der havde talt om at rejse til Kolding, opgav deres beslutning, da det blev bekjendt, at han ville lade sig høre her, og nu bliver de skuffede i deres forventning.

På den anden side var det heldigt, at planen ikke blev udført; den havde ikke længere ladet sig udføre. I eftermiddag modtog jeg nemlig fra politimesteren en skrivelse, der lyder:

Die Polizeiverwaltung.

Hadersleben d. 9. Dec. 1887.

Ihre bisherigen mündlichen Anfragen ob gegen hiesige Vorträge Bjørnstjerne Bjørnsons auch wenn Eintrittsgeld erhoben würde etwas zu erinnern sei, sind diesseits verneint worden, da der Unterzeignete aus der Litteratur - hauptsächlich freilich nur Zeitungslitteratur - erkannt zu haben glaubte dass bei den gedachten Vorträgen zweifellos ein höheres Interesse der Wissenschaft obwalte. Diese Meinung kann indes dem Artikel ("Modersmaalet " 9. 12.) gegenüber nicht aufrecht erhalten werden und wird Ihnen daher hierdurch mitgeteilt, dass Vorträge der bezeigneten Art von der hiesigen Polizeiverwaltung nicht werden zugelassen wordens.

Die Polizeiverwaltung

B. Chemnitz.

De vil heraf se, at foredraget havde måttet tilbagekaldes, hvis Bjørnson ikke forinden havde ændret planen, og dette ville dog have været langt ærgerligere. Saa vidt jeg ved, inskrænkede den antydede artikel $\mathrm{i}$ "Modersmaalet sig kun til nogle fä linier, der i grunden ikke omhandler selve foredragets indhold, men hvori der til slutning bemærkes, at $\mathrm{Bj}$. havde skænket indtægten i Kolding til sønderjyderne og overleveret den til L. Schrøder. Det er selvfølgelig denne slutbemærkning, der har 


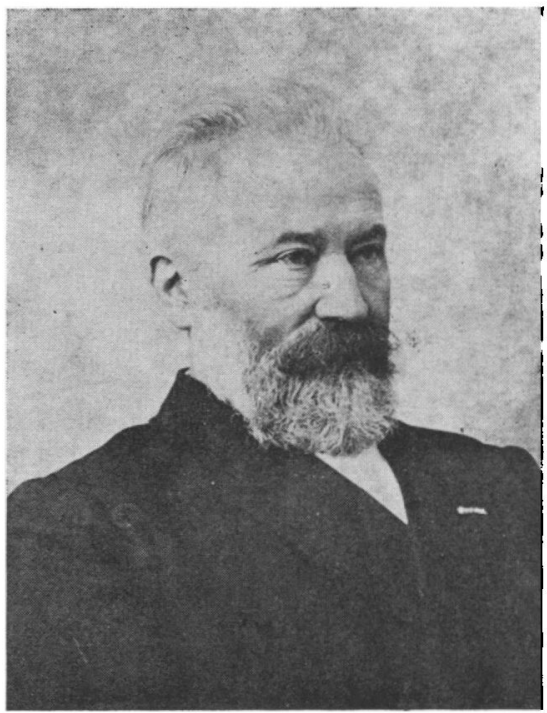

Ludvig Schrøder

bragt politimesteren til at forandre sin opfattelse af sagen og tage den givne tilladelse tilbage - heldigvis bagefter. - -

Bjørnson havde d. 8. dec. talt i Kolding, og mødet fik et særligt festligt forløb, idet han den dag fyldte 55 år. Efter mødet skrev han til Otto Borchsenius : "Du kan gærne offentliggøre fra mig, at dette har ikke været en rejse, men et eventyr, og det endte som alle eventyr med et stort bryllup; det stod i Kolding den 8. december". Der var mødt ca. 1000 tilhørere, der modtog hans tale med stor begejstring, der ikke blev mindre, da han meddelte, at han ville give indtægten af mødet til sønderjyderne.

Det store møde gav et pænt overskud på ikke mindre end $900 \mathrm{kr}$., som Bjørnson overlod til Ludvig Schrøder til uddeling. Denne uddeling har også sin historie. Schrøder var da landstingsmand, og d. 14. dec. skrev han fra Rigsdagen hjem til sin kone ${ }^{7}$ : -I morges var H. P. Hanssen-Nørremølle hos mig. Han vil jo til Berlin efter jul, og jeg sagde ham, det var heldigt, om han bagefter kunne gøre en rejse i Sverige og Norge, og at jeg ikke vidste nogen bedre måde at anvende Bjørnsons penge på end at støtte ham til at få sin uddannelse afsluttet. Han har måttet låne hos faderen for at kunne være i Leipzig og København, og han har 
måttet holde sig tilbage for meget, der ellers kunne have betydning for ham, for at spare pâ pengene. Vil du ikke spørge la Cour om hans mening, og synes I to som jeg, da kan I lige så godt give ham alle de $900 \mathrm{kr}$. mod hans kvittering - hvori der gerne skulle stå, at han havde modtaget pengene til afslutning af sin uddannelse på en rejse til Berlin, Sverige og Norge - når han en af dagene kommer til Askov. Pengene ligger i min sorte taske. Jeg sagde idag til Bjørnson, at jeg havde tænkt på en sådan anvendelse af pengene, og han havde intet dertil at bemærke. Har I betænkelighed ved at give $H$. P. H. dem alle, kan $I$ jo foreløbig give ham $500 \mathrm{kr}$."

Øjensynligt har la Cour og fru Schrøder haft betænkeligheder ved kun at lade en enkelt nyde godt af den bjørnsonske gave, for da Schrøder endelig - næsten to ár efter - den 24. septbr. 1889 sender Bjørnson regnskab for pengenes anvendelse ${ }^{8}$, meddeler han, at $\mathrm{H}$. P. Hanssen har fået $500 \mathrm{kr}$. til et ophold i Berlin, Jens F. Jørgensen $150 \mathrm{kr}$. til et ophold i København, og to unge piger, Jing Callesen ${ }^{10}$ og Kirstine Jensen (Jessen) ${ }^{11}$ deler resten. Schrøder ledsager regnskabet med følgende oplysninger om de udvalgte "At H. P. Hanssen har en fremskudt stilling i Sonderjylland, som sekretair for Vælgerforeningen og som medudgiver af "Sønderjyske Årbøger", har næppe undgâet din opmærksomhed. Jens F. Jørgensen har bl. a. uddannet sig i Kjøbenhavn til at kunne oplæse nordiske forfatteres skrifter i Sønderjylland. De to unge piger hører til de flinkeste lærlinge, vi har haft fra Sønderjylland, og det kan ventes, at de hver på sit sted vil hjælpe til at bevare det danske modersmál og forholdet til dansk historie og til danske sange hos børnene og derved øve en modvægt imod den germanisering, hvorpå der arbejdes i skolerne."

H. P. Hanssen har ikke straks som af Schrøder foreslået fået de $500 \mathrm{kr}$. i 1887, og de er ikke bleven anvendt i Berlin, men til en Norges-rejse. Den 13. maj 1891 skriver Morten Eskesen til Bjørn$\operatorname{son}^{12}$, at han på en Norgesrejse til sommer foruden P. Skau og Poulsen, Bovlund, vil have den unge H. P. Hanssen $i$ sit følge. "Du har selv udstyret ham med penge. Det vil sige, han får $200 \mathrm{kr}$. af de penge, Du ved mødet i Kolding stillede til rådighed. " Mange år efter fortæller H. P. Itanssen, at Schrøder en dag overraskede ham med en gave fra $B$ jornson på $300 \mathrm{kr}$., som han efter 
hans ønske skulle bruge til en rejse til Norge. Med gaven fulgte en venlig hilsen og en indbydelse til på denne rejse at aflægge ham et besøg på Aulestad. Da H. P. Hanssen om sommeren kom til Aulestad, var Bjørnson imidlertid ikke hjemme, men han traf fru Caroline Bjørnson ${ }^{13}$.

Men disse penge skulle dukke op engang igen. I 1897 var Bjørnson i Kobenhavn og blev her interviewet af en af "Politiken "s journalister. I dette interview, der står i bladet 26 . nov., og som er undertegnet "Index", fortæller Bjornson, at det netop er ti år siden, han talte $\mathrm{i}$ Kolding og da "følte lyst til at gøre noget for andre på min fødselsdag. Så lod jeg indtægten af mit foredrag gå til sønderjyderne. Det blev $1000 \mathrm{kr}$., som jeg sendte til Ludvig Schrøder på Askov, og Schrøder anvendte denne sum på bedste måde. Han nærede netop interesse for en ung mand, en af hans tidligere elever. Til denne unge mand gav han pengene og sagde: "Rejs til Berlin, søg kundskab og sæt dig ind i de offentlige forhold «, og den unge mand rejste. Hvad han har læert, har man senere set $\mathbf{i}$ Slesvig. På denne lille tildragelse har jeg ofte tænkt med glæde, og jeg har takket Schrøder for, at disse penge fandt den rigtige mand."

Da H. P. Hanssen læste dette, blev han af flere grunde forskrækket. Han skrev med det samme ${ }^{14}$ til Schrøder: Uden at mit navn nævnes, er der dog sigtet så bestemt til mig, at det næppe vil kunne misforstås, og Jessen har derfor også straks grebet lejligheden til at aftrykke de págældende steder i "Flensborg Avis". Meddelelsen er meget uklog og uheldig i øjeblikket, da retssagen angâende Bjørnsons sang: "Jeg vil værge mit land" netop er svævende, og den er jo tilmed usand i denne form. Af de omtalte 1000 kr. har jeg, som De sikkert endnu vil erindre, fảet $300 \mathrm{kr}$., ikke til et studieophold i Berlin, mit ophold var allerede den gang endt, men til en rejse til Norge, hvor jeg skulle holde en del foredrag om den sønderjyske sag, og de er også bleven brugt dertil. Hensigten med disse linier er, da sagen også vil kunne blive mig ubehagelig i Berlin, at bede Dem om at oplyse i "Flensborg Avis", at de $1000 \mathrm{kr}$. ikke er bleven brugt på denne måde. Om De offentlig vil gøre rede for, hvortil de er blevet brugt, det må jeg overlade til Dem. I så fald kan De godt nævne, at jeg har fået $300 \mathrm{kr}$. til den nævnte rejse for at fremme min uddannelse og 
samtidig virke for udbredelsen af kendskab til den sønderjyske sag. Hvis derimod den anden meddelelse, hvor der er sigtet så bestemt til mig, at det ikke vil kunne misforstås, ikke dementeres nu af Dem, vil den gå igen $i$ det uendelige i de tyske blade og stridsskrifter og vedvarende berede mig mange ubehageligheder. *

Schrøder har svaret ved at sende ham det før nævnte brev af 14. dec. 1887, men har øjensynligt ikke sendt "Flensborg Avis " det ønskede dementi. Den 10. dec. takker H. P. Hanssen ham for de to breve, han har fået. Han må erkende, at han har husket fejI m. h. t. summen - den var på $500 \mathrm{kr}$. - men han skrev sit brev i hast, da han stod overfor at skulle rejse til Als. Men han kan nu konstatere, at den tyske presse mod forventning ikke har lagt mærke til Bjørnsons udtalelser, og "derved er grunden til at røre mere ved denne sag for mit vedkommende bortfalden. "Den skal have lov at hvile, når den ikke påny fremdrages for offentligheden.

Og det er den øjensynligt ikke blevet, før H. P. Hanssen i 1928 skrev en artikel om "Bjørnstjerne Bjørnson og Sønderjylland * $\mathbf{i}$ „Dansk Udsyn". Han har da glemt Schrøders oplysning om summens størrelse og gentager, at han har fået $300 \mathrm{kr}$. af Koldingpengene.

NOTER:

1. I Landsarkivet i Ảbenrå.

2. V. Mussmann var ejer af $>$ Mariegaard\& i Haderslev.

3. P. A. Madvig.

4. J. H. Bjørnshauge var redaktør af 'Dannevirke . M. C. Mathiesen var redaktionssekretær, men forholdet mellem de to mænd var ikke godt, og Mathiesen onskede at opgive sin stilling.

5. Deres foreløbige mundtlige forespørgsel, om der var noget at erindre mod Bjørnstjerne Bjornsons foredrag her, selv om der også blev taget adgangspenge, er fra vor side besvaret benægtende, da undertegnede fra litteraturen - ganske vist hovedsagelig aviser mente at have erkendt, at det planlagte foredrag var af højere videnskabelig interesse. Denne mening kan imidlertid ikke opretholdes $\mathrm{i}$ betragtning af denne artikel (i *Modersmaalet $\times$ ), og det meddeles Dem derfor herved, at foredrag at næunte art ikke vil blive tilladt af den herværende politiforvaltning.*

6. Bjornstjerne Bjørnsons Brevveksling med Danske 1875 - 1910 I, 312.

7. I H. P. Hanssens arkiv, Landsarkivet i Ãbenrå.

8. Bjørnstjerne Bjørnsons Brevveksling med Danske 1875-1910, I, 341, 421. 
9. Jens Feilberg Jørgensen er den senere frimenighedspræst i Skærbæk. Elev på Askov 1884-87. Iflg. Askov Højskoles forhandlingsprotokol har A. D. Jørgensen anbefalet ham til denne støtte.

10. Jing Callesen, der er datter af Nis Callesen, Lerskov, var elev på Askov 1888-89. Da hun i 1895 blev viet til gdr. Hans Friis, Kopsholt, i sit hjem af frimenighedspræst L. B. Povlsen, gav det anledning til, at myndighederne afskedigede Nis Callesen som kirkexldste og medlem af provstisynoden. Denne behandling af en af Sønderjyllands mest agtede bonder vakte stor opsigt.

11. I »Brevveksling " I, 421 kaldes hun s Kirstine Jensen", men i Askovs elevprotokol fra disse år er der ingen af dette navn; derimod er der en Kirstine Jessen fra $\varnothing$. Lindet, der er elev 1887-88 og 1888-89. Hun har de fineste vidnesbyrd fra skolen, og det er efter al sandsynlighed hende, der har fået pengene. Hun var datter af malermester Jessen, der havde Sprogforeningens bogsamling i $\emptyset$. Lindet. Hun samlede de unge piger til håndgerning og højtlæsning og begyndte pigegymnastikken i hendes faders rummelige værksted. Hun blev i 90'erne gift med sit bysbarn Anton Bro og fik sit hjem i Gredsted i Jernved sogn ved Ribe, hvor hun dode i 1898. (Et sønderjysk Forsamilingshus, $\emptyset$. Lindet, 1946. s. 21 ).

12. "Brevveksling « II, 65,384 .

13. DDansk Udsyn« 1928, 37.

14. Brev 27. 11. 1897. Schrøders Arkiv (Kgl. Bibl.). 